\title{
Plasenta Tüketimi ve Olası Yarar-Zarar Profili
}

\section{Placenta Consumption and Probable Benefit-Damage Profile}

\author{
Neriman GÜDÜCÜ̈, Neslihan KESER ÖZCAN ${ }^{\mathrm{b}}$
}

ÖZ Plasenta tüketimi (placentophagy); doğum sonrası plasentanın ve bileşenlerinin değiştirilmiş (pişmiş, kurutulmuş, sıvı içinde demlenmiş) veya değiştirilmemiş (herhangi bir işleme uğramamış) formda annenin kendisi ya da herhangi biri tarafından yenmesidir. Plasentanın imhasına dair kültürlerarası farklılıklar bulunmaktadır. Bazı kültürlerde plasentanın imhası için kullanılan prosedürler, annenin gelecekteki sağlı̆̆ını koruyucu önlemler olarak işlev görürken, bazılarında çeşitli hastalıkları iyileştirme aracı olarak görülmekte, bazılarında ise hastalıkların kaynağı olarak değerlendirilmektedir. Bazı araştırmacılar plasentanın östrojen, progesteron, laktojen, demir, $\beta$-endorfinler ve oksitosin de dahil olmak üzere çeşitli hormonlar ve besinler açısından oldukça zengin olduğunu ve bu zenginliğin doğumdan sonra da plasentada kaldığını öne sürmüştür. Böylece plasenta tüketiminin, annenin doğum sırasında kaybettiği besin maddelerini, hormonlarını tekrar yerine koyması için bir aracı olabileceği, bu sayede postpartum ruh halinin düzenlenmesinin sağlandığı, maternal bağlanmayı desteklediği, bağışıklığı güçlendirdiği, ağrıyı azalttığı, yorgunluğu ve anemiyi önlediği, doğum sonu kanamayı engellediği, laktasyonu ve demir düzeylerini arttırdığı, saç ve deri dokusunu iyileştirdiği düşünülmektedir. $\mathrm{Bu}$ derlemede plasenta tüketiminin, geçmişten günümüze kültürden külttüre değişen ritüelleri ve olası yararları, zararları güncel bilgiler ışığında tartışılarak, doğum öncesi, doğum ve doğum sonu hizmetlerinde sorumluluğu olan sağlık çalışanlarının konuya dikkatini çekmek amaçlanmıştır.

Anahtar sözcükler: Plasenta; plasenta tüketimi; maternal plasenta tüketimi

\begin{abstract}
Placentophagy is the consumption of postpartum placenta and its components in the modified (cooked, dried, or brewed in liquid) or unmodified (unprocessed) form by the mother herself or any other person. There are intercultural differences in disposing of the placenta. The procedures used for disposing of placenta in some cultures are deemed as protective measures for the future health of the mother, while these procedures are considered as means of healing for or as sources of various diseases in some other cultures. Some researchers suggest that placenta is quite rich in terms of various nutrients and hormones including estrogen, progesterone, lactogen, iron, $\beta$-endorphins and oxytocin, and assert that this richness remains in the placenta after the birth. Therefore, it is thought that consumption of placenta may be used as a means of restoring the mother's nutrients and hormones lost during the birth, which makes the mother regain her postpartum mood. It is also thought that placenta consumption may support maternal-infant bonding, strengthen immunity, reduce postpartum pains, relieve tiredness and anemia, prevent postpartum hemorrhage, increase lactation and iron level, thicken hair, and heal skin texture. This review aims to draw attention of health professionals working in prenatal, delivery and postnatal services to the placenta consumption, by examining the changing rituals of consumption of placenta from past to present and discussing the possible benefits-damages of consumption of placenta in the light of up-to-date information
\end{abstract}

Keywords: Placenta; placentophagy (placenta consumption); consumption of maternal placenta

\section{Giriş}

Plasenta kan damarları sayesinde memeli bir yavruyu annesinin uterusuna bağlayan, anne ile fetus arasında gaz alışverişi, fetusun beslenmesi, fetusun metabolizma atıklarının eliminasyonu, anneden fetusa antikor transferi, bazı hormon ve opioidlerin üretimi ve düzenlenmesi, fetusun zararl1 maddelere maruziyetten korunması gibi farklı görevleri olan oldukça karmaşık bir yapıdır (1-3). Plasenta doğumdan sonra, deri kan akımını ve elastik liflerin esnekliğini arttırdığı gerekçesiyle kozmetik alanında ve içerdiği hormon ve elementlerden dolayı farklı formlarda tüketilmesi suretiyle sağlık alanında kullanılabilmektedir (2$10)$.

Plasenta tüketimi (plasentophagy); doğum sonras1 insan plasentasının ve bileşenlerinin (amniyon sıvısı ve ilişkili zarlar) değiştirilmiş (pişmiş, kurutulmuş, sıvı içinde demlenmiş) veya değiştirilmemiş (herhangi bir işleme uğramamış) formda anne ya da herhangi biri tarafindan yenmesidir. Plasentanın maternal olarak tüketilmesi; annenin doğum sonrası kendi plasentasını herhangi bir zamanda herhangi bir formda yemesi; plasentanın maternal olmayan tüketimi ise

Geliş Tarihi/Received:07-12-2017/ Kabul Tarihi/Accepted:09-04-2018

a Arş. Gör., İstanbul Üniversitesi, Sağlık Bilimleri Fakültesi, Ebelik Bölümü, İstanbul, ORCID: 0000-0001-9365-5337

b Doç. Dr., İstanbul Üniversitesi, Sağlık Bilimleri Fakültesi, Ebelik Bölümü, İstanbul, ORCID: 0000-0003-1311-6646

Sorumlu yazar /Correspondence: Arş. Gör. Neriman GÜDÜCÜ, İstanbul Üniversitesi Sağllk Bilimleri Fakültesi Ebelik Bölümü, İstanbul, e-mail: nerimanteker@windowslive.com 
plasentanın anneden başka herhangi bir kişi tarafindan herhangi bir zamanda alınması olarak tanımlanmıştır $(2,3,8,11)$. Plasentaya dair inanç ve uygulamaların bilinmesi, plasenta tüketiminin doğum sonrası iyileşme, duygudurum değişiklikleri ve süt üretimi ile ilişkisi, geçmişten günümüze kimler tarafından uygulandığının bilinmesi yarar ve zararlarını tartışabilmek açısından önemlidir.

\section{Geçmişten Günümüze Plasentayla İlgili Kültürel Ritüeller}

Plasentayla ilgili çeşitli kültürel ritüeller bulunmaktadır. Young ve Benyshek (2010), kültürlerarası plasental inançların ve uygulamaların incelenmesinde 179 toplumun etnografik kültürel bir araştırmasını gerçekleştirmişlerdir. $\mathrm{Bu}$ araştırmaya göre 109 kültürde toplam 169 kabul edilebilir imha yönteminin olduğu saptanmıștır. Gömü, en yaygın bertaraf yöntemidir ve bildirilen uygulamaların 93'ü (\%55) organın gömülmesi biçimindedir. Birçok kültür, gömü için evin bahçesi veya doğum yerinde belirli bir yer tespit etmiştir. Diğer uygulamalar çok daha nadir görülen uygulama-lardır. Bu nadir uygulamalardan biri de plasentayı gömmeden bir yerlere yerleştirmektir $(\% 14,8)$. Bu uygulamalar plasentayı göle atmak, bazılarında yakmak, bazılarında ağaca asmak veya yerleştirmek olarak raporlanmıştır. Bu uygulamalarda en s1k belirtilen inanç, plasentanın anne ve bebeği tedavi edeceği, geleceği değiştireceği veya tahmin edeceğidir. Kuzey Amerika Seminolünün geleneksel inançların da, plasentanın gömüldüğü deliğin üzerine ağır bir kaya konulması durumunda gelecekteki gebeliklerin önlenebileceği, yine bazı bölgelerde plasentanın gömüldüğü ağacın büyüme biçiminin çocuğun sağlığını öngöreceğine inanılmaktadır. Bazı bölgelerde de tıpkı Antik Mısır'da olduğu gibi plasentanın çeşitli hastalıkları önleme ve iyileştirme aracı olarak görülmesinin yanında, hastalıkların kaynağı olarak da kabul edildiği rapor edilmiştir. Araştırmaya dahil edilen kültürlerin yaklaşık \%18'inde bir hayvanın plasentay 1 yemesi ya da temas etmesine izin verilirse anneye veya çocuğa zarar gelebileceğine, \%11,9'unda plasentanın kirli veya kirletici veya bulaşıcı bir etkiye sahip olduğuna inanıldığı belirlenmiştir (3).

Davidson'un Latin Amerika'da yaptığ 1 bir çalışmaya göre en sık rastlanan plasenta imha yöntemi gömü ve akan suya atmak olarak belirlenirken, bu yöntemin kullanılma nedeni olarak da geleneklere uymak ve anne ve bebeğin zarar görmesini engellemek olarak açıklanmıştır. $\mathrm{Bu}$ araştırmaya dahil edilen 45 yaşında bir kadın plasentayla ilgili şunları söylemiştir: "Anne vücudunda iki yaşam taşır; biri bebeğin biri de plasentanın. Bebek doğar doğmaz plasenta gömülmeli, eğer gömülmezse, bebeğe verilen ilgiyi kıskanacaktır ve bu kıskançlık köyde bir salgın yaratacaktır." Bu insanlar plasentanın yaşadığına ve eğer düzgün gömülmezse, topluluklarına zarar verme potansiyeline sahip olduğuna inanmaktadırlar ve bu nedenle plasentayı gömmeden önce gereken özen ve saygıyı göstermek adına onu koka yaprakları, çeşitli otlar, şeker, alkol ve/veya örümcek ağına sararak gömme işlemini gerçekleştirmektedirler (12). Plasentanın bu sihirli ve görünmeyen gücü Jung'un gölge arketipini çağrıştırmaktadır. Jung'a göre, gölge insanın yardımsever doğasının tam tersi, tüm kötülüklerin kaynağıdır. Doğum sürecinde gölge, yaşayan bebeğe eşlik eden taraf olarak plasenta ile temsil edilir. Bebeğin tanınabilir insan formu onu bilindik, tanıdık ve kabul edilebilir k1larken, plasenta şekilsiz, belirsiz ve kötülük yapma potansiyeline sahiptir. Bebek anneye ve topluma sevinç katarken, plasenta ölüm ve talihsizliğin habercisi olarak algılanabilmektedir. Bebeğin karanlık tarafidır. Plasentaya dikkatli yaklaşılmalıdır, dikkatsizlik korkunç sonuçlar doğurabilir (13).

\section{Plasenta Tüketimi}

Bazı araştırmacılar plasentada östrojen, progesteron, laktojen, demir, $\beta$-endorfinler ve oksitosin de dahil olmak üzere çeşitli hormonların ve besinlerin bulunduğunu (2-8) ve bunların doğumdan sonra da plasentada kaldığını öne sürmüştür. Böylece plasenta tüketiminin, annenin doğum sirasında kaybedilen besin maddeleri ve hormonlarını tekrar yerine koyması için bir firsat sağlayabileceği ve plasentadan alınacak bu maddelerin kadının doğum sonu ruh halinin düzenlenmesi (postpartum depresyonun önlen-mesi) ve fiziksel iyileşme hızını artırmasına katkı sağlayacağına inanılmıştır $(2,3)$. Plasenta tüketiminin aynı zamanda maternal bağlanmayı teşvik ettiği, bağışıklığ güçlendirdiği, ağrıy1 azalttığ1 $(2,6,14-16)$ yorgunluğu önlediği, doğum sonu kanamayı bastırdığ 1 , laktasyonu ve demir düzeylerini arttırdığı, saç ve deri dokusunu iyileştirdiği ve uygulamaya katılanların çoğunda doğum sürecinden uterus iyileşmesine kadar 
yardımcı olduğu düşünülmektedir (2). Memeli hayvanlar doğumlarında plasentalarını yerken bu uygulama günümüzde insanlarda çok yaygın olmayan bir durumdur. Plasenta yenilmesine bilimsel ilgi ancak 1970'lerden sonra olmasina rağmen çok eski tarihlerde kültürel bir uygulama olduğuna ilişkin kanıtlara rastlanmaktadır. Plesantanın yenilmesiyle ilgili ilk yazılı bilgiye Talmud'da rastlanılmaktadır ve çok zayıf ve solunum güçlüğü çeken bir çocuğa yardım için ilaç olarak önerilmiştir (12). Maternal plasenta yenilmesini işaret eden ilk tıbbi kaynak, on altıncı yüzyılda tıbbi özelliklere sahip maddelerin Çinli bir kayd1 olan "Compendium Materia Medica" dir. Bu kitapta bir metin, insan plasentasının tıbbi kullanımına yönelik bir bölüm ayırmakta ve "doğum yapan kadın, plasentasını yer" ifadesini içermektedir (3).1935 yılında İtalyan kadınların, süt üretimini arttırması ve ağrılarını azaltması için plasentalarını yedikleri bilinmektedir (17). 1970' lerde Kuzey Amerika'da bu durum bir gelenek olarak belgelenmiştir (6,16,18-20). Bir kasabada yaşayan genç bir kadın doğumunu arkadaşlarının yardımıyla yapmış, doğumdan sonra buharda pişirdiği plasentasını diğer kişilerle paylaşarak yemiş ve "harika bir yenilenme ve harika bir lezzet" olarak nitelendirmiştir (18).

Plasentanın çiğ olarak yenilmesinin yanında kurutulmuş olarak tüketimine yine Çin tıbbında rastlanmaktadır. Kurutulmuş insan plasentası için Çin terimi olan $\mathrm{Zi} \mathrm{He}$ Che kullanılmaktadır ve doğum sonrası insanlarda çeşitli hastalıkların (örneğin, iktidarsızlık, karaciğer ve böbrek problemleri, infertilite, anemi ve düşük enerji) tedavisinde kullanılmıştır $(2,3,6,16)$.

Haiphong'da Çekoslovak-Vietnam Dostluk Hastanesinde çalışan bir patolog tarafından 19581960 yıllarında Kuzey Vietnam dağlarında yaşayan Çinli ve Taylandlı kabilelerin plasentayı kotiledonlarına ayırarak soğanla kızartıp yedikleri belirlenmiştir (18). Davidson'un aktardığına göre, Peru'da görüşülen bir kişi, plasentayı yakıp, küllerini su ile karıştırdıklarını ve bu karışımı içecek olarak kullandıklarını belirtmiştir. $\mathrm{Bu}$ içeceğin, hayvanlara fertilitelerini arttırmak için verildiği ve bazen de zor ve uzun süreli bir doğumu hızlandırmak için doğum sırasında verildiği belirtilmiştir. Kolombiya'da, soğuk ve ölü gibi görünen bir bebeği canlandırmak için plasentanın 1sitıldığı anekdotuna rastlanmıştır (12).

\section{Plesanta Tüketiminin Olası Yararları ve Zararları}

Progesteron, demir, kalsiyum ve oksitosin gibi baz1 bileşenlerin varlığ1 termde plasentada gösterilmiş olmasına rağmen (4,5,21-23), bunların bakımı, hazırlığı ve çiğ dokuda dayanıklılığı, ayrıca doğum sonrasi yenilmesinin kadın üzerindeki etkileri demir düzeyi haricinde test edilmemiştir. Plasentanın uyku sorunları, enfeksiyonlar, cilt ve saç sorunlar1, menstruasyon ve menopoz sirasında yaşanan güçlükler gibi sorunlarda da kullanılabileceği ön görülmekle beraber, bu kullanımı destekleyecek bilimsel veri yoktur (16). Diğer taraftan plasenta steril değildir. Plasentanın bir fonksiyonu da, fetusu zararlı maddelere maruziyete karşı korumaktır. Selenyum, kadmiyum, cıva ve kurşun gibi elementlerin yanı sıra bakteriler de plasentanın bu süzgeç görevinden dolayı post-term plasental dokularda bulunabilir (4,7,24-27). Postpartum dönemde uterus kaynaklı ya da kontaminasyona bağlı olarak bakteri ya da virüsler plasenta dokularında kalabilir. Böyle bir plasentanın postpartum dönemde yenilmesinin bebeğe potansiyel olumsuz etkileri bilinmemektedir (16).

Gebe kadınlar gebelikleri boyunca çok çeşitli yabancı kimyasallara maruz kalmaktadır. $\mathrm{Bu}$ maruziyet genellikle, maternal ilaçlar, sigara, alkol, madde tüketimi veya mesleki ve çevresel kaynaklar gibi yaşam tarzı faktörlerinden kaynaklanmaktadır. Çevresel maruziyet coğrafi olarak değişkenlik gösterebilir. Örneğin, plasental kurşun ve kadmiyum seviyeleri kentsel-endüstriyel alanlarda kırsal alanlardan daha yüksektir. Bu maddelere maruziyet değerlendirmesi genellikle kan veya idrar laboratuvar incelemesine dayanmaktadır. Kadmiyum gibi ağır metaller genellikle gebelik sirasında plasental dokuda biyolojik olarak birikir. Sigara kullanımı da plasental selenyum, çinko ve kadmiyumu arttırır $(7,28)$. Bir çalışmada sigara içen annelerin plasentalarındaki progesteron miktarının sigara içmeyen annelerin plasentalarında bulunanın yaklaşık yarısı olduğu gösterilmiştir (29). Azalan progesteron seviyeleri, kadmiyum seviyelerinin yükselmesi ile korelasyon göstermiştir. Gebelik sırasında kadmiyuma maruz kalmanın, over hormonlar1 özellikle de östradiol üretimini etkilediği gösterilmiştir (30).

Diğer çevresel metallerden veya zararlı maddelerden hangilerinin tek başına veya kombinasyon ile evrimsel geçmişimizde 
plasentalarını tüketen annelerin üreme sağlığına önemli ölçüde zarar vermiş olabileceği kesin olarak bilinmemektedir. Yüksek dozda metale maruz kalmak, annelerin üreme sağlığını çeşitli yollarla azaltabilir. Kadmiyum, solunum yoluyla alınan ve dolaşıma katılan toksik bir metaldir ve vücuda girdiğinde, bir takım doku ve organlara zarar verebilme kapasitesine sahiptir. Yapılan incelemeler kadmiyumun karaciğer, böbrekler ve overler dahil olmak üzere üreme organlarında biriktiğini göstermektedir. Birkaç çalışma, kadmiyumun bir endokrin bozucu olarak işlev gördüğünü ve düşük doz maruziyetin bile üreme hormonlarının üretimini ve işlevini etkilediğini kanıtlamaktadır. Bitkiler, büyüme sırasında toprakta biriken metalleri tuttuğu için tütün yapraklarında bulunan kadmiyum, sigara aracilığıyla solunur ve dolaşıma katılır. Sigara içen annelerin plasentalarında yükselmiş kadmiyum düzeyleri bulunmuştur $(29,31)$. Plasenta tüketimi kısa süreli bir uygulama olsa bile eğer plasenta çok yüksek bir toksik konsantrasyon içeriyorsa, annenin ve bebeğin (emzirme yoluyla) sağlığına uzun süreli zararlı sonuçlar doğurabileceği unutulmamalıdır (19).

Ağır metaller dişında plasentada $\beta$ endorfin (PBE) bulunmaktadır. PBE gebeliğin son trimesterinde üretilmeye başlanır ve doğuma kadar maternal plazmada artışını sürdürür. Doğum esnasında ağrıyı azaltmada ve anneyi annelik davranışlarına hazırlamada işlev görür. Anne tüm yatırımını var olan gebeliğine yapamaz, türünün devamı için sonraki gebelikleri için de var olan kaynaklarını en uygun şekilde kullanmak zorundadır. Oysa annenin kendisi için belirlediği bu en uygun kullanım fetüs için yeterli değildir ve daha fazla kaynak elde edebilmek için fetüs PBE aracılığı ile anneyi manipüle etmektedir. Endorfin intrauterin ebeveyn-yavru çatışmasına aracılık eder, diğer bir deyişle fetüslerin annelerini endorfine bağımlı hale getirdiği ve plasentaya besin öğesi tahsis edilmesini arttırdığı düşünülmektedir. İnsanlarda doğum sonu psikolojik belirtilerin (annelik hüznü, depresyon ve psikoz), endorfinyoksunluk belirtileri olarak yorumlanabilen bu mekanizmanın yan etkileri olduğu savunulmaktadır. Doğumdan hemen sonra plasentanın yenilmesi, fetal manipülasyonun negatif yan etkilerini azaltmada etkili bir strateji olarak değerlendirilebilir. Yani kadının doğum ağrısının giderilmesi ve doğum sonu psikolojik değişikliklerin etkisinin azaltılması için plasenta tüketimi bir alternatif olarak görülebilir. Hayvanlarda içgüdüsel olarak görülen plasenta yemenin biyolojik kaynağ aslında PBE'nin yarattığı bir istek olarak yorumlanmaktadır. Zaten bir süre sonra anne sütü ile indüklenen, maternal hipofizin endorfin salın1mi, anneyi daha fazla yoksunluk semptomundan kurtaracak bir işlev görmektedir. Üzerinde yeterli bilimsel kanitlar olmasa da anekdotal olarak rapor edilen doğumun hemen ardından plasenta yiyen annnelerde de görülen öforik haller, plesantadaki PBE etkisi olarak değerlendirilmektedir (15).

Gebeliğin son trimesterinde ve doğumda plasentanın yüksek düzeyde salgıladığı ve depoladığ1 kortikotropin salıcı hormon (CRH), stresle daha iyi baş etmeye ve postpartum depresyonu önlemeye yardımcı olmaktadır (6). Plasenta CRH'ı gebelik öncesindeki miktarından 60 ile 700 kat daha yüksek seviyelerde anne kan dolaşımına salmaktadır (32). Hipotalamustan CRH salınmas1, HPA (Hipotalamik-Pitüiter-Adrenal) eksen döngüsünü başlatır ve hipofizden periferik kan dolaşımına adrenokortikotropik hormonun (ACTH) salınmasin1, dolayısıyla da kortizol salınmasını tetikler (33). Plasental kaynaklı CRH $(\mathrm{pCRH})$ ise, HPA ekseni aktivitesinde ters rol oynamaktadır. pCRH hipotalamusu etkileyerek daha önce salgilanan kortizole tepki olarak CRH üretimini düşürürken, kortizole maruz kalan plasental doku da pCRH üretimini arttırır. Bu HPA ekseni aktivitesinin düzensizliği, gebelik boyunca pCRH düzeylerinin katlanarak artmasına ve diğer HPA ürünlerinde (örneğin kortizol ve ACTH gibi) daha 1lımlı artışlara neden olur. Doğum sonrası dönem, HPA ekseni tarafindan pCRH'in geri çekilmesi için yeniden ayarlama zamanı olarak düşünülebilir. Gebelikte anormal derecede yüksek pCRH düzeyleri, doğumdan hemen sonra ani bir düşme göstermektedir. $\mathrm{Bu}$ ani düşmenin riskli bireylerde postpartum depresyonu tetiklediği varsayılmaktadır (33-36). Hahn-Holbrook, gebeliğin son trimesterındaki yüksek pCRH düzeylerinin doğum sonu depresyonu öngördügünü iddia etmektedir (33). Aynı şekilde Iliadis ve ark. da 17. gebelik haftasındaki yüksek CRH düzeyleri ile postpartum depresif belirtilerin gelişimi arasında bir ilişki saptamıştır (37). Daha sonra pek çok çalışmada da depresif durumlar ile beyindeki yüksek $\mathrm{CRH}$ seviyeleri ilişkilendirilmiştir (38-41). Depresyonda HPA ekseni aktivitesinin düzensizliği de bilinen etiyolojik faktörlerdendir. 
Depresif belirtiler ile pCRH arasında ilişki bulamayan çalışma sonuçları da bulunmaktadır. Rich-Edwards ve ark. yükselmiş pCRH düzeylerinin doğum öncesi depresyon semptomları ile aynı yönde ilişkide iken, doğum sonrası depresyon ile arasında ise herhangi bir ilişki olmadığını (42); Meltzer-Brody ve ark. ise doğum öncesi ve doğum sonrası depresyon semptomları ile $\mathrm{CRH}$ düzeyleri arasında ilişki olmadığını bildirmiştir (43). Aynı şekilde Glynn ve Sandman da doğum sonrası depresyon semptomları ile CRH düzeyleri arasında ilişki olmadığını saptamıştır (44). Bu çelişkili araştırma sonuçları, $\mathrm{CRH}$ düzeyleri ile perinatal depresyon belirtileri arasındaki ilişkiye dair daha fazla çalışmaya gereksinim olduğunu göstermektedir. Perinatal depresyon ile annenin demir depoları arasında ilişki kuran çalışmalar da bulunmaktadır. Bazı araştırmacılar plasenta tüketiminin annenin demir depolarını destekleyerek, annenin enerjisinin artacağını ve dolaylı olarak postpartum depresyonu önleyeceğini bildirmişlerdir (6). Beard ve ark. postpartum depresyonun, demir eksikliği anemisi ile ilişkili olduğunu ve demir takviyesinin depresyonu tedavi edebileceğini belirtmişlerdir (45). Başka bir çalışmada da düşük hemoglobin düzeylerinin depresif belirtilerin görülme olasılığını arttırdığı bildirilmektedir (46). Ancak demir düzeyleri ile postpartum depresyon arasında herhangi bir ilişki olmadığını bildiren çalışmalar da mevcuttur (4749). Çalışma sonuçlarına baktığımızda, plasentada varlığ 1 gösterilen progesteron, oksitosin, endorfin gibi hormonların ve demir gibi elementlerin plasenta tüketimi yoluyla alımının yararları konusunda hala bir fikir birliğinin olmadığ görülmektedir.

Selander ve ark. 18 yaş üstü, internet kullanan ve en az bir çocuğun doğumundan sonra plasentasını kapsülleterek tüketen 189 kadının dürtü ve deneyimleri üzerine yaptıkları internet tabanlı bir çalışmada; katılımcıların yaklaşık yarısı (\%49) daha önce doğum sonu bir duygudurum bozukluğu (\%24'ü annelik hüznü, \%19'u anksiyete ve \%47'si depresyon) yaşadığını bildirmiştir (2). $\mathrm{Bu}$ kadınların \%52'si duygudurum bozukluğunun ciddiyetini "hafif" ve \%43'ü "şiddetli" olarak tanımlarken; küçük bir azınlığı, rahatsızlığını "çok ciddi" (\%3) veya "çok hafif" (\%2) olarak değerlendirmiştir. Plasentasını kapsül olarak tüketen 103 kadının \%34'ü ruhsal durumunu iyileştirmek için bu yolu denediğini söylerken,
$\% 40$ '1 bu tüketimin duygu durumlarının düzelmesine katk1 sağladığını bildirmiştir. Katılımcıların \%26'sı enerji artışı, \%15'i de emzirmeyi iyileştirmesi ve \%7'si de doğum sonu kanamayı engellemesi için plasenta tükettiklerini bildirmiştir. Kişisel olarak bildirilen diğer olumlu etkiler; aneminin önlenmesi veya tedavi edilmesi, canlılık duygusunun artışı, kilo kaybı, baş ağrılarının önlenmesi/rahatlaması, bebekle bağlanmayı desteklemesi, ağrının azalması, hormonların yenilenmesi/düzenlenmesi, uyku kalitesinin veya süresinin artış1, uterus involüsyonu ve libido artış1 olarak sıralanmıştır. Tek yaygın olarak belirtilen olumsuz etki hoş olmayan tat ve koku olarak belirlenmiş, bunu da baş ağrısı (\%4) izlemiştir. Katılımciların \%20'si, plasenta tüketimiyle ilgili hoş olmayan yönlere de değinmiştir; bunlar kapsül almayı hatırlamakta güçlük çekme, uterus kramplarında artma, vajinal kanamada artma, sindirim güçlüğü, enfeksiyon, sıcak basması, sosyal stigma, mide bulantısı, aşırı laktasyon, konstipasyon, cilt lekelerinde artış, bebeğin etkilenmesi (döküntü gibi) ve kapsülleme işlemiyle ilgili kaynak sınırlığ 1 ve maliyetidir. Araştırmaya katılanların \%98'i bu yöntemi tekrar kullanacağını bildirmiştir.

Plasenta tüketimiyle ilgili bilgi ve tutumların değerlendirildiği internet tabanlı başka bir çalışmada, \%78,7'sinin kadın, \%19,9'unun erkek olduğu 216 kişiden sadece 6 kadın ve 1 erkek pişmiş, bir kadın da çiğ plasenta yediğini belirtmiștir. Plasenta yemeyi tecrübe eden katılımcılar, besleyici ve tıbbi olarak yararlı olduğu için veya bir ebe tarafından önerildiği için plasenta yediklerini bildirmişlerdir. Katılımcıların yaklaşık dörtte biri $(\% 26,8)$ doğum sonu depresyonun önlenmesi de dahil olmak üzere bildirilen sağlik yararlarından dolayı gelecekte de plasenta yemeyi düşündüklerini bildirmişlerdir. Plasental dokuyu yeme istekliliğinde, cinsiyet veya etnik köken üzerinde anlamlı bir farklılık bulunmamıştır (50).

Young ve Benyshek, Afrika, Asya, Avrupa, Amerika, Karayipler, Orta Doğu ve Okyanusya topluluklarını içeren 179 topluma ait kültürlerarası plasental inançları ve uygulamaları inceledikleri sistematik bir araştırmada, maternal plasenta tüketimine sadece Meksikalılarda rastladıklarını bildirmişlerdir (3). Yine aynı araştırmacılar plasentanın maternal olmayan tüketimiyle ilgili üç farklı durum belirlemiş̧lerdir. Birincisi babanın plasenta ve kanını pişirdikten 
sonra yemesi, ikincisi çocuğun kendi plasentasından yapılan çayı içmesi (çocuğa musallat olacak kötü ruhları engellemek için), son olarak ta tüberküloz hastalarının hastalıktan kurtulmak için plasentayı yemesi biçimindedir. Asya, Orta Amerika / Karayipler, Güney Amerika, Afrika ve Ortadoğu'da çok az sayıda toplum plasentanın infertilite, ayaklardaki çatlaklar, kellik gibi durumların tedavisinde etkinliğine dair inançlarını dile getirmiştir. Bazı topluluklarda ise plasentanın kirli veya bulaşıcı olduğuna inanıldığı rapor edilmiştir (3).

Maternal plasenta tüketimini savunanlar, plasenta tüketiminin laktasyonu geliştirdiğini iddia etmişlerdir. Çekoslavakya'da, Soykov'aPachnerov'a ve ark. tarafindan yapılan eski tarihli bir çalışmada plasenta yenilmesinin süt üretimine fizyolojik etkileri araştırılmıştır (51). Dondurularak kurutulmuş insan plasentaları ile beslenen 210 katılımcının \%86's1 süt salınımı "iyi" (süt üretiminde en az 20 gr artış) veya "çok iyi" (en az 30 gr artış) olarak bildirilmiştir. Araştırmacılar, annelerin kendi plasenta dokularını mı yoksa donör plasentasını mı aldıklarını açıklığa kavuşturmamışlardır. $\mathrm{Bu}$ araştırmada kontrol grubu bulunmamasina rağmen, dondurularak kurutulmuş plasenta ile beslenen 21 kadından 7'sinde süt üretiminde "pozitif" bir artış görülürken, plasentayı kurutmadan yiyen 21 kadından 14'ünde süt artışı görülmemiştir. Ancak, bu çalışma sonuçlarının yorumlanmasında, metodolojisinin güncel bilimsel kriterlere uygun olmaması nedeniyle dikkat edilmelidir $(6,16)$. Blank ve Friesen'in siçanlarda yaptığı çalışma da, laktasyon ve doğum sonrası hormonların düzenlenmesine katkıları nedeniyle, plasenta tüketiminin yararlı etkilerini destekleyen bir kanıt olarak gösterilmiştir. Plasenta yiyen dişi sıçanlarda daha yüksek prolaktin düzeyi belirlenmiştir (52).

Plasenta tüketiminin diğer bir yararı da, postpartum dönemde opioid aracılı analjeziyi artırmasidır (53,54). Bu mekanizma kemirici hayvanlarda belirlenmiş olup, diğer memeli türlerinde de benzer mekanizmaların olabileceği savunulmuştur $(2,6,53)$. Kristal ve arkadaşları, doğum sonras1 plasenta ve eklerinin $-20^{\circ} \mathrm{C}$ 'de dondurulduğu durumlarda, plasenta ve eklerinde bulunan POEF'in (Plasental Opioid Arttirici Faktör) faydalı etkilerinin (analjezi gibi) aylarca korunduğunu bildirmişlerdir. Yararlı etkilerin oda sıcaklığında 24 saat sonra azaldığı belirlenmiştir.
Dondurulmuş dokunun etkisini $35^{\circ} \mathrm{C}$ ile $40^{\circ} \mathrm{C}$ 'ye kadar koruyabildiği, daha yüksek sicaklıklarda etkisini kaybettiği saptanmıştır (55).

Plasenta aynı zamanda fetal genomu taşıyan ve bu nedenle de bir allogreft olarak işlev gören immünolojik açıdan aktif bir organdır. Fetüs, maternal bağışıklık sistemi tarafından reddedilmeyen, paternal antijenleri de içeren antijenik bir karışıma sahiptir. Buna göre, plasentanın yutulmas1, özellikle Rh uyumsuzluğu bulunan gebeliklerde zarar verebilecek alloimmünizasyonu tetikleyebilir (56).

Plasental dokuda bol miktarda bulunan östrojen ve progesteron, doku reddi ile ilgili immünolojik süreçleri bastırır. Plasental doku yutulmas1, doğumdan sonra uterusta kalan plasental hücrelerin artmasina neden olabilir ve bu da anneye tehdit oluşturabilir ve koryokarsinoma yol açabilir. Bununla birlikte, bunlar sadece varsayımdır ve henüz bunları destekleyen hiçbir bilimsel kanit bulunmamaktadır (56).

Hastal1k Kontrol ve Önleme Merkezi (CDC), kontamine olmuş plasenta kapsüllerinin alınmasının, geç başlangıçlı B grubu streptococcus agalactiae'nin (GBS) enfeksiyonlarına neden olabileceği konusunda anektodal vakalardan yola çıkarak uyarılarda bulunmaktadır (57). Plasenta kapsüllerinin yetersiz 1s1 ile hazırlanması, HIV, hepatit virüsü veya zika virüsü gibi virüsleri ortadan kaldırmak için yetersiz kalabilmektedir (56).

Plasenta tüketimiyle ilgili web tabanlı bilgi içeren sitelerin sayısı ve bu bilgilere ziyaretçi erişimi son yıllarda önemli ölçüde artmıştır. Örneğin, 2006 yılında plasenta yeme ile ilgili kadınlara bilgi sağlamak ve annelerin postpartum iyileşmesini desteklemek için (http://PlacentaBenefits.info) web sitesi kurulmuş-tur. 2007'de, plasenta kapsülleme konusunda uzman arayışına yönelik artan talebe yanıt olarak "Plasenta Fayda Organizasyonu-(PBİ)" aracılı̆̆ıyla plasenta kapsülleme uzmanı yetiştirme programları başlatılmıştır (2).

\section{Sonuç}

Plasenta yemeyle ilgili hayvan araştırmaları daha çok maternal temas ve ağrı eşiği ile ilgili iken; insanlarla ilgili araştırmalar doğum sonrası iyileşme, duygu durum bozukluğu ve süt üretimi üzerine odaklanmaktadır (8). Davidson ise, plasenta ritüellerinin doğumla ilgili anksiyeteyi 
azaltma mekanizmaları olarak hizmet ettiğini ileri sürmektedir (12).

Plasenta tüketiminin insanlarda laktasyonu artırması, uterusun involüsyonunu kolaylaştırması veya hormon seviyelerini modüle etmesine yardımcı olduğu iddialarını destekleyecek veriler yeterli değildir. İncelenen araştırmalara dayanarak, insan sağlığı ile ilgili herhangi bir sonuç çıkarmak mümkün değildir.

Plasenta tüketimiyle ilgili ciddi risklerin olabileceği de her zaman dikkate alınmalıdır. Eldeki bilgilere dayanarak, plasenta tüketilmesinin terapötik yararlarını ve güvenliğini daha iyi tanımlamak için insan organizmasına en yakın hayvanlar üzerinde yapılacak daha fazla bilimsel araştırmaya ihtiyaç vardır.

Özetle; bu derleme, başta ebeler ve kadın doğum uzmanları olmak üzere tüm sağlık çalışanlarına plasenta tüketimi ile ilgili yapacağı bilimsel araștırmalara zemin olușturması, son zamanlarda hizla artan konuyla ilgili merak ve taleplere cevap verebilmesi, bireylere riskler ve faydalarla ilgili danışmanlık verebilmeleri ve profesyonel olarak sorumlu bir yaklaşım sergileyebilmeleri için kaynak oluşturması açısından önemlidir.

\section{Kaynaklar}

1. Taşkın L. Gebeliğin oluşumu ve fetusun fizyolojisi. Doğum ve Kadın Sağlığı Hemşireliği. Genişletilmiş XIII. Baskı. Ankara: Akademisyen Tip Kitabevi; 2016. p.75.

2. Selander J, Cantor A, Young SM, Benyshek DC. Human maternal placentophagy: A survey of self-reported motivations and experiences associated with placenta consumption. Ecol Food Nutr. 2013; 52(2): 93-115.

3. Young SM, Benyshek DC. In search of human placentophagy: a cross-cultural survey of human placenta consumption, disposal practices and cultural beliefs. Ecology of Food and Nutrition 2010; 49: 467-484.

4. Young SM, Gryder LK, David WB, Teng Y, Gerstenberger S, et al. Human placenta processed for encapsulation contains modest concentrations of 14 trace minerals and elements. Nutrition Research 2016a; 36: 872878.

5. Young SM, Gryder LK, Zava D, Kimball DW, Benyshek DC. Presence and concentration of
17 hormones in human placenta processed for encapsulation and consumption. Placenta 2016b; 43: 86-89.

6. Beacock M. Does eating placenta offer postpartum health benefits? $\mathrm{Br} \mathrm{J}$ Midwifery 2012; 20(7): 464-469.

7. Myllynen P, Pasanen M, Pelkonen O. Human placenta: A human organ for developmental toxicology research and biomonitoring. Placenta 2005; 26(5): 361-371.

8. Marraccini ME, Gorman KS. Exploring placentophagy in humans: problems and recommendations. Journal of Midwifery \& Women's Health 2015; 60(4): 371-379.

9. Mevlitoğlu İ, Engin B, Kaplan M. Yaşlanmayı geciktiren ürünler ne kadar etkili?. Archives of the Turkish Dermatology \& Venerology/Turkderm 2009; 43(1): 2-6.

10. Kim BY, Kim TG, Kang WY, Baek H, Cheon $\mathrm{HY}$ et al. Functional cosmetic effect of porcine placeta. Korean Chemical Engineering Research 2010; 48(3): 327-331.

11. Kristal MB, DiPirro JM, Thompson AC. Placentophagia in humans and nonhuman mammals: causes and consequences. Ecology of Food and Nutrition 2012; 51: 177-197.

12. Davidson JR. The shadow of life: Psychosocial explanations for placenta rituals. Culture, Medicine and Psychiatry 1985; 9(1): 75-92.

13. Jung CG. Man and his symbols. Anchor Press. New York 1964.

14. DiPirro JM, Kristal MB. Placenta ingestion by rats enhances y- and n-opioid antinociception, but suppresses a-opioid antinociception. Brain Research 2004; 1014: 22 - 33

15. Apari P, Rozsa L. Deal in the womb: Fetal opiates, parent offspring, conflict, and the future of midwifery. Med Hypotheses 2006; 67(5):1189-1194.

16. Coyle CW, Hulse KE, Wisner KL, Driscoll KE, Clark CT. Placentophagy: therapeutic miracle or myth? Arch Womens Ment Health 2015; 18(5): 673-680.

17. Ploss H, Bartels M, Bartels P. "Woman: An historical, gynaecological and anthropological compendium. Whitefriars Press. London 1935.

18. Ober WB. Notes on placentophagy. Bull N Y Acad Med. 1979; 55(6): 591-599.

19. Young SM, Benyshek DC, Lienard P. The conspicuous absence of placenta consumption in human postpartum females: The fire 
hypothesis. Ecology of Food and Nutrition 2012; 51:198-217.

20. Enning C. Placenta: The gift of life. Motherbaby Press. Eugene, Oregon 2007.

21. Sakamoto M, Yasutake A, Domingo JL, Chan HM, Kubota M. et al. Relationships between trace element concentrations in chorionic tissue of placenta and umbilical cord tissue: Potential use as indicators for prenatal exposure. Environ Int. 2013; 60: 106-11.

22. Manci EA, Blackburn WR. Regional variations in the levels of zinc, iron, copper, and calcium in the term human placenta. Placenta 1987; 8(5): 497-502.

23. Phuapradit W, Chanrachakul B, Thuvasethakul $\mathrm{P}$, Leelaphiwat $\mathrm{S}$, Sassanarakkit $\mathrm{S}$, et al. Nutrients and hormones in heat-dried human placenta. J Med Assoc Thai. 2000; 83(6): 690694.

24. Aagard K, Ma J, Antony KM, Ganu R, Petrosino $\mathrm{J}$ et al. The placenta harbors a unique microbiome. Sci Transl Med. 2014; 6(237):111.

25. Stout MJ, Conlon B, Landeau M, Lee I, Bower $\mathrm{C}$ et al. Identification of intracellular bacteria in the basal plate of the human placenta in term and preterm gestations. Am J Obstet Gynecol. 2013; 208(3): 226.e1-7.

26. Fardini Y, Chung P, Dumm R, Joshi N, Han YW. Transmission of diverse oral bacteria to murine placenta: evidence for the oral microbiome as a potential source of intrauterine infection. Infect Immun. 2010; 78: 1789-1796.

27. Osman K, Akesson A, Berglund M, Bremme $\mathrm{K}$, Schütz A et al. Toxic and essential elements in placentas of Swedish women. Clin Biochem. 2000; 33(2): 131-138.

28. Kantola M, Purkunen R, Kroger P, Tooming A, Juravskaja J, et al. Selenium in pregnancy: Is selenium an active defective ion against environmental chemical stress? Environ Res. 2004; 96: 51-61.

29. Piasek M, Blanus M, Kostial K, Laskey JW. Placental cadmium and progesterone concentrations in cigarette smokers. Reproductive Toxicology 2001; 15: 673-681.

30. Eisenmann CJ, Miller RK. Cadmium and glutathione: Effect on human placental thromboxane and prostacyclin production. Reprod Toxicol. 1995; 9(1): 41-48.
31. Shiverick KT, Salafia C. Placenta, cigarette smoking and pregnancy I: Ovarian, uterine and placental effects. Placenta 1999; 20: 265-272.

32. Campbell EA, Linton EA, Wolfe CDA, Scraggs PR, Jones MT, et al. Plasma corticotropin-releasing hormone during pregnancy and partition. Journal of Clinical Metabolism 1987; 64 (5): 1054-1059.

33. Holsboer F. Stress, hypercortisolism and corticosteroid receptors in depression: implications for therapy. Journal of Affective Disorders 2001; 62 (1-2): 77-91.

34. Hahn-Holbrook J, Schetter CD, Arora C, Hobel CJ. Placental corticotropin-releasing hormone mediates the association between prenatal social support and postpartum depression. Clinical Psychological Science 2013; 1(3): 253-265.

35. Vitoratos N, Papatheodorou DC, Kalantaridou SN, Mastorakos G. "Reproductive" corticotropin-releasing hormone. Annals of the New York Academy of Sciences 2006; 1092: 310-318.

36. Hochberg Z, Pacak K, Chrousos GP. Endocrine withdrawal syndromes. Endocrine Reviews 2003; 24(4): 523-538.

37. Iliadis SI, Sylv'en S, Hellgren C, Olivier JD, Schijven D, et al. Mid-Pregnancy corticotropin-releasing hormone levels in association with postpartum depressive symptoms. Depression And Anxiety 2016; 33: 1023-1030.

38. Chrousos GP, Torpy DJ, Gold PW. Interactions between the hypothalamic-pituitary-adrenal axis and the female reproductive system: Clinical 1mplications. Annals of Internal Medicine 1998; 129(3): 229-240.

39. Smith SM, Vale WW. The Role of the hypothalamicpituitary- adrenal axis in neuroendocrine responses to stress. Dialogues In Clinical Neuroscience 2006; 8: 383-395.

40. Gold PW, Licinio J, Wong ML, Chrousos GP. Corticotropin releasing hormone in the pathophysiology of melancholic and atypical depression and in the mechanism of action of antidepressant drugs. Annals of the New York Academy of Science 1995; 771: 716-729.

41. Arborelius L, Owens MJ, Plotsky PM, Nemeroff CB. The role of corticotropinreleasing factor in depression and anxiety 
disorders. Journal of Endocrinology 1999; 160 (1): $1-12$.

42. Rich-Edwards JW, Mohllajee AP, Kleinman K, Hacker MR, Majzoub J, et al. Elevated midpregnancy corticotropin-releasing hormone is associated with prenatal, but not postpartum, maternal depression. J Clin Endocr Metab. 2008; 93(5): 1946-1951.

43. Meltzer-Brody S, Stuebe A, Dole N, Savitz D, Rubinow D, et al. Elevated corticotropin releasing hormone $(\mathrm{CRH})$ during pregnancy and risk of postpartum depression (PPD). J Clin Endocr Metab. 2010; 96(1): 40-47.

44. Glynn LM, Sandman CA. Evaluation of the association between placental corticotrophinreleasing hormone and postpartum depressive symptoms. Psychosom Med. 2014; 76(5): 355362.

45. Beard JL, Hendricks MK, Perez EM, MurrayKolb LE, Berg A, et al. Maternal iron deficiency anemia affects postpartum emotions and cognition. J Nutr. 2005; 135(2): 267-272.

46. Corwin EJ, Murray-Kolb LE, Beard JL. Low hemoglobin level is a risk factor for postpartum depression. J Nutr. 2003; 133(12): 4139-4142.

47. Armony-Sivan R, Shao J, Li M, Zhao G, Zhao $Z$, et al. No relationship between maternal iron status and postpartum depression in two samples in China. J Pregnancy 2012: 521431.

48. Paterson JA, Davis J, Gregory M. A study on the effects of low hemoglobin on postnatal women. Midwifery 1994; 10(2): 77-86.

49. Gryder LK, Young SM, Zava D, Norris W, Cross CL et al. Effects of human maternal placentophagy on maternal postpartum iron status: A randomized, double-blind, placebocontrolled pilot study. Journal of Midwifery \& Women's Health 2017; 62(1): 68-79.

50. Cremers GE, Low KG. Attitudes toward placentophagy: A brief report. Health Care for Women International 2014; 35: 113-119.

51. Soykov'a-Pachnerov'a E, Brutar V, Golov'a B, Zvolsk'a E. Placenta as a lactagogon. Gynaecologia 1954; 138(6): 617-627.

52. Blank MS, Friesen HG. Effects of placentophagy on serum prolactin and progesterone concentrations in rats after parturition or superovulation. J Reprod Fertil 1980; 60(2): 273-278.

53. DiPirro JM, Kristal MB. Placenta ingestion by rats enhances $\mathrm{Y}$ - and $\mathrm{N}$-opioid antinociception, but suppresses a-opioid antinociception. Brain Research 2004; 1014: 22-33

54. Kristal MB. Enhancement of opioid-mediated analgesia: A solution to the enigma of placentophagia. Neurosci Biobehav Rev. 1991; 15: 425-35.

55. Kristal MB, Abbott P, Thompson AC. DoseDependent enhancement of morphine-induced analgesia by ingestion of amniotic fluid and placenta. Pharmacology Biochemistry And Behavior; 1988; 31(2): 351-356.

56. Farr A, Chervenak FA, McCullough LB, Baergen RN, Grunebaum A. Human placentophagy: A review. American Journal of Obstetrics and Gynecology 2017.

57. Buser GL, Mato S, Zhang AY, Metcalf BJ, Beall B et al. Notes from the field: Late onset infant group B streptococcus infection associated with maternal consumption of capsules containing dehydrated placentaOregon, 2016. Morbidity and Mortality Weekly Report (MMWR) 2017; 66: 677-678. 